\title{
The Research of Type of Sheet Pile Interaction Based on ABAQUS
}

\author{
Jie $A i^{1,}$ a , Jin song Gui ${ }^{1, ~ b, ~}{ }^{*}$, Jia song Wang ${ }^{1, ~ c}$, Ding Chen ${ }^{1}$
}

${ }^{1}$ School of Marine and Civil Engineering, Dalian Ocean University, Dalian, Liaoning 116023, China

a814648486@qq.com, bouijs@163.com (*corresponding author), c1255613005 @qq.com

\begin{abstract}
Keywords: Flexible wall; Sheet pile retaining wall; Sheet pile wharf.; ABAQUS; Type of sheet pile interaction; Earth pressure

Abstract. There are important significance for sheet pile structure of $3 \mathrm{~d}$ modeling to set reasonably the mode of action between two sheet piles.For the study of rational mode between the sheet pile, the international general finite element software- ABAQUS is used in this passage to have established the different mode of action on Sheet pile of finite element numerical calculation model, It calculates both the earth pressure on the structure of retaining wall from different types of Sheet pile interaction under the same conditions. The results show that the earth pressure on the sheet pile wall all presents " $R$ " type distribution, under the different types of Sheet pile interaction the earth pressure on the sheet pile is slightly different.Therefore, when the sheet pile structure calculation, it should set reasonably interaction type between the sheet pile, according to the actual connection between the sheet pile.
\end{abstract}

\section{Introduction}

Sheet pile wall is generally flexible wall and the overall deformation is dominated by bending deformation, with failure mode being bending failure, also called flexible damage. The main load on the sheet pile wall is earth pressure. At present in the conventional design of the earth pressure on the sheet pile wall generally take principal and passive earth pressure under limit state, however,because of the sheet pile wall being embedded by soil solid and supported by the anchorage structure in the practical engineering, displacement of structure is restricted. The actual earth pressure behind the wall is not in the limit state, but the result of the interaction between sheet pile and soil ${ }^{[1]}$. There are many factors to influence on the active earth pressure redistribution on the sheet pile wall, such as the bottom of the built-in depth, the anchor rod height and spacing, and the way of connection between sheet pile,etc, this passage emphatically analyze the earth pressure on the sheet pile wall by the influence of the sheet pile connecting method.

Sheet pile wall is the vertical plate strip retaining structures using to resist lateral earth pressure, it can be divided into two types of steel sheet pile and reinforced concrete sheet pile. In the construction process, the connection between steel sheet pile is usually welding or riveting connection; and the connection between reinforced concrete sheet pile is so many, such as plane type joint, joint pipe joint, the embedded joint etc ${ }^{[2]}$, In numerical simulation, the connection between steel sheet pile is usually simplified as hinged to simulate; While connections between reinforced concrete sheet pile is more complicated, this passage use the four ways of the rigid connection, hinge joint, contact and non-contact to simulate four types of pile interaction that are embedded joint, joint pipe joint, plane type joint and plate joint state. Without considering lateral displacement of the sheet pile wall along the wharf shoreline direction, We have some preliminary conclusions through simulation of sheet pile comparative analysis in different pile interaction.

The finite element analysis software ABAQUS developed and maintained by Sauder SIMULIA company has been widely accepted by global industry and academia. ABAQUS is well-equipped with the constitutive model reflecting the character of soil authentically, being able to perform the calculation of effective stress. It evolves powerful interface-processing functions to simulate the release between soil and structure, the phenomenon such as slip, and the ability of handling the specific problems in geotechnical engineering process such as filling and excavation., Moreover, it can set up the initial stress state flexibly, and it has a strong applicability to calculate the retaining wall structure ${ }^{[3]}$. 


\section{The simplified model}

In the passage, three kinds of different width of the sheet pile model with rigid connection is established, which is $10 \mathrm{~m}, 5 \mathrm{~m}$ width, $2 \mathrm{~m}$ wide, to analyze the impact on the symmetry of load and structure on the results.

Taking $5 \mathrm{~m}$ wide area of the sheet pile wall, we can respectively set up four pile interaction models which is the rigid connection, hinge joint, contact and non-contact:

1 ,The rigid connection is no relative displacement between two model interface, it can be set to merge;

2, Hinge joint,is that two model surface only can be allowed relative rotation along the axial direction, it can be set densely "hinge" to simulate on the centerline of the two contact surfaces from top and bottom;and also can bind the centerline of the two contact surfaces to simulate through "Tie"(" Tie "constraint effect: the two sides in the model is strong bond together, no longer apart in the process of analysis. Two sides are bound can have different geometry and grid ${ }^{[4]}$ ).

3 , Contact is the contact relations between the two models. In Abaqus, the two entities or an assembly of two area is in contact with each other on the spatial location, but Abaqus will not automatically think they have this contact relation. This paper simulates the two types of contact between the two sheet pile, frictionless condition and friction condition, at the same time vertical direction respectively analysis with linear and nonlinear on the friction state.

4 , Non-contact is to simulate the slab joint state between the two sheet pile which isn't set any action.

According to the symmetry of load and the structure, we can take wide area of sheet pile wall in the direction perpendicular to the axisand the soila certain range before and after the retaining wallto establish finite element model .To analyze the soil pressure, we can take foundation area of width 5 timesmore than wall's width from two sides of the wall, to eliminate the influence of boundary constraints on both ends. We can take soil layer of thickness 1.0-1.5 times thicker than that of height of the wall in Vertical direction, to eliminate the influence of the bottom boundary constraints.

When making model ,the sheet pile wall model will be $20 \mathrm{~m} * 1 \mathrm{~m} * 0.4 \mathrm{~m}$ (height $*$ width $*$ thickness), $10 \mathrm{~m}$ deep in soil.Soil model size will be $40 \mathrm{~m} * 40 \mathrm{~m} * 5 \mathrm{~m}$ (height * width * thickness) in shorter side; $50 \mathrm{~m} * 60 \mathrm{~m} * 5 \mathrm{~m}$ (height $*$ width $*$ thickness) in high side. More information and data please refer to table 1 .

The boundary before and after the model is the symmetry constraint around $\mathrm{Z}$ plane ,the left and right boundary is the pole constraints in the vertical chain of $X$ plane ,the bottom is clamped constraints.X direction chain Pole constraints is imposed on the part of flexible retaining wall which is $1 \mathrm{~m}$ distance from the top of wall .Soil structure and the mutual coupling, non-linear problem belongs to the boundary conditions, by defining contact to simulate the contact.Consideringthe relative sliding, separation and periodic off and on of the contact surfaces, according to the laws of the sliding, we can use small sliding between point and surface tosimulate the relative sliding. Contact surface tangential role will be defined by a friction formula. The average friction coefficient between the structure and the soil is 0.3 and it's the same between the two sheet pile. The Normal function use "hard" formula that only passing pressure don't pull. Retaining wall and soil adopts linear reduced integral unit 8 node hexahedron C3D8R, and select the type of Hex mesh. According to the edge of cloth kind retaining wall grid size is $1 \mathrm{~m}$, the soil grid size is $2 \mathrm{~m}$.As shown in figure 1 .

Table 1: Calculation of material parameters

\begin{tabular}{|c|c|c|c|}
\hline \multirow{2}{*}{ parameter } & \multirow{2}{*}{ unit } & \multicolumn{2}{|c|}{ material } \\
\cline { 3 - 4 } & & concrete & soil \\
\hline $\mathrm{E}$ & $\mathrm{Pa}$ & $3.15 \mathrm{E} 10$ & $10 \mathrm{E} 6$ \\
\hline $\mathrm{v}$ & & 0.3 & 0.3 \\
\hline$\gamma$ & $\mathrm{kN} \cdot \mathrm{m}-3$ & 25 & 16.8 \\
\hline$\phi$ & $\left(^{\circ}\right)$ & & 33.7 \\
\hline $\mathrm{c}$ & $\mathrm{kPa}$ & & 10 \\
\hline
\end{tabular}




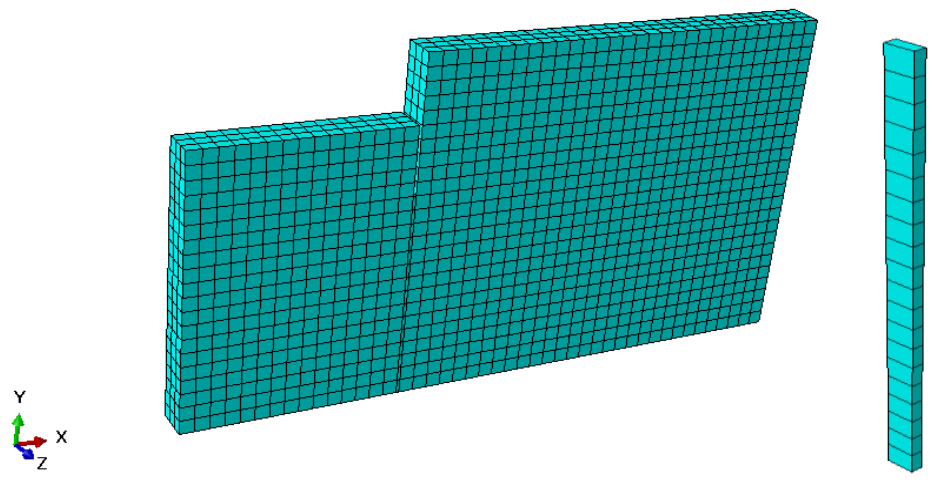

Figure 1: The sheet pile wall finite element meshes

\section{The earth pressure analysis of the sheet pile wall}

\subsection{Symmetry effect on the sheet pile wall (units:KPa)}

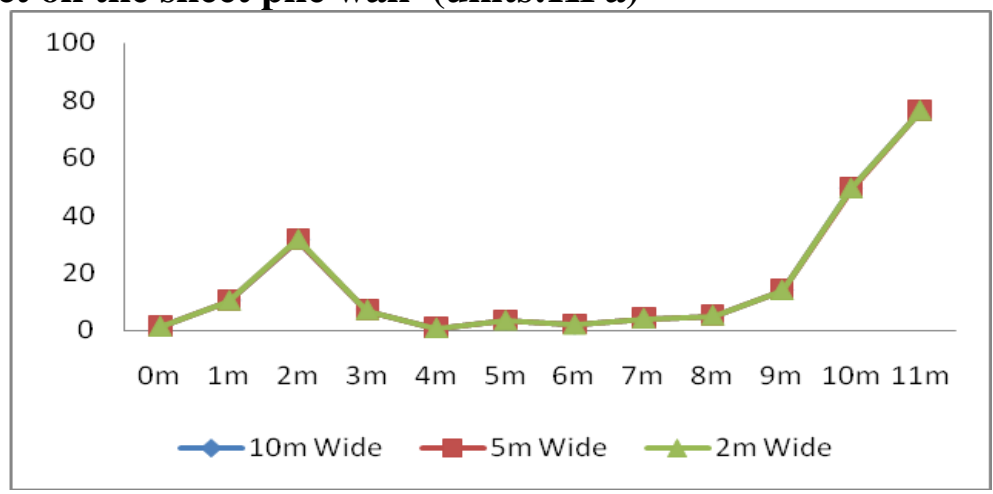

Figure 2: The earth pressure on the sheet pile wall of different width

Curve is basically coincide in the model selected $10 \mathrm{~m}, 5 \mathrm{~m}, 2 \mathrm{~m}$ wide, This shows sheet pile wall has good symmetry,so there is good representativeness to analyze a certain period of the wharf.

3.2 The distinguish between frictionless condition and friction condition with sheet pile contacting and the distinguish between linear and nonlinear with setting the contact type (units:KPa)

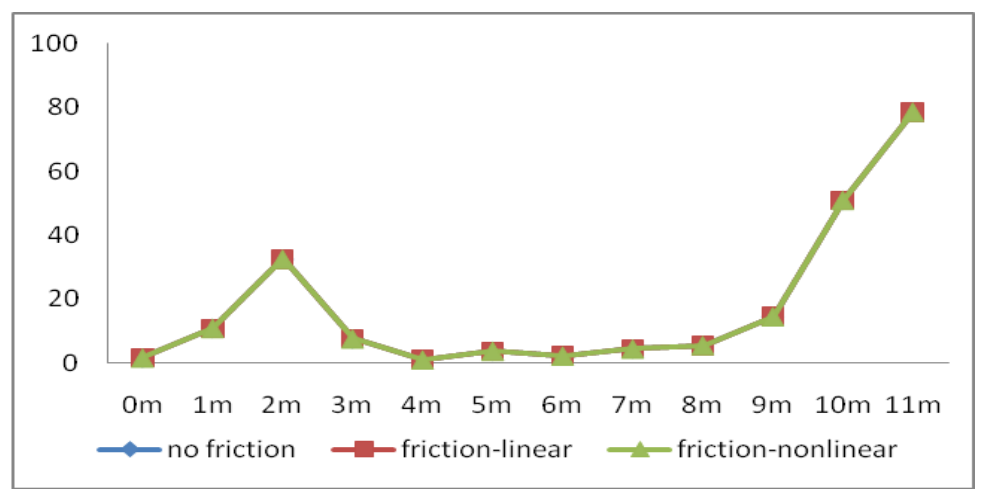

Figure 3: The earth pressure on the sheet pile wall of different contact parameters

The distinguish of the earth pressure on the sheet pile wall between frictionless condition and friction condition is very small, and as well as between the linear and nonlinear. It can be concluded that the friction affected the earth pressure very little on the sheet pile wall when the concrete sheet pile type contacting. 


\subsection{The distinguish between "Tie" constraints and "hinge" connection when it set to hinged between sheet pile (units:KPa)}

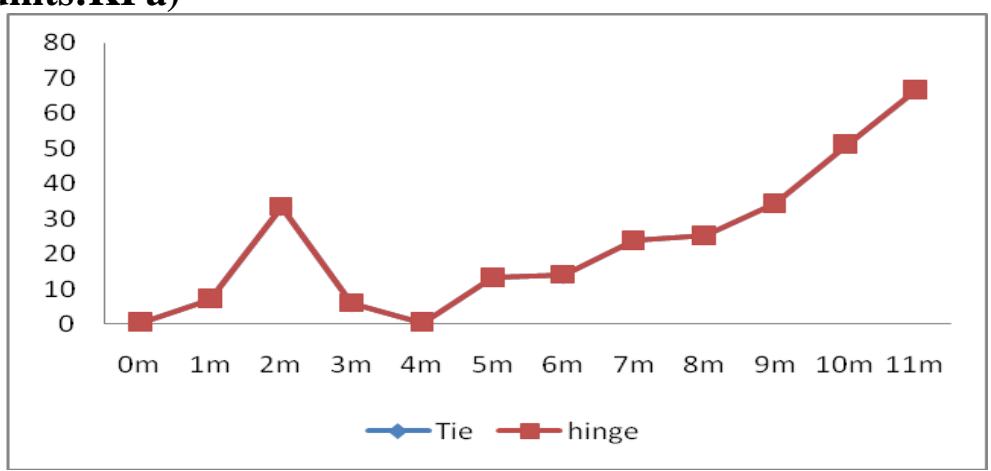

Figure 4: The earth pressure on the sheet pile wall of two hinged types

"Tie" and "hinge" connection types have no difference in the articulated set, the two curves coincide.

\subsection{The distinguish of four sheet pile interaction types (units:KPa)}

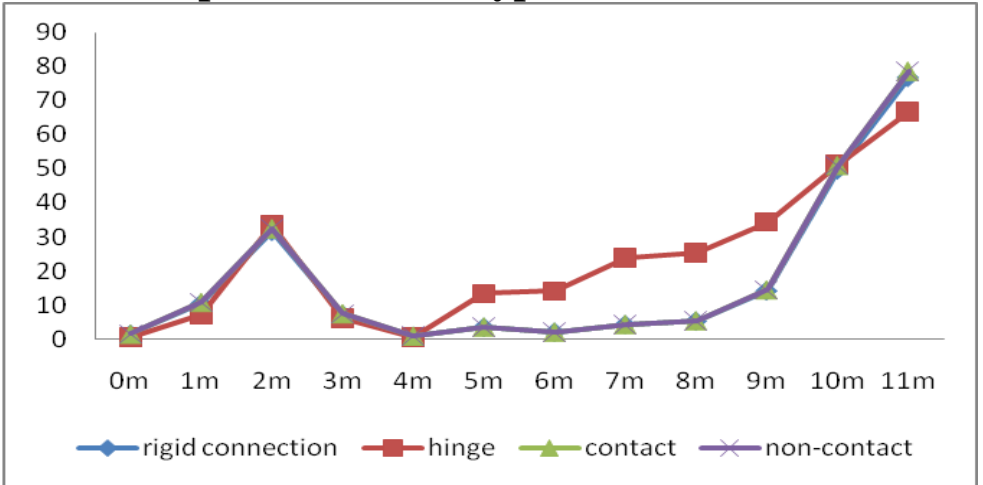

Figure 5: The earth pressure on the sheet pile wall of four pile interaction types

Four types of pile interaction: rigid connection, hinge joint, contact and non-contact, The curves of rigid connection, contact and non-contact coincide basically ,but articulated state, The earth pressure at the bottom of sheet pile wall (under the anchor end to the grave side) grows first, is basically positively related to growth, while the other three states the earth pressure on the sheet pile wall is slower growth, increase sharply near to the grave.

\section{Conclusion}

(1) This numerical simulation,with using the ABAQUS finite element software to simulate, the earth pressure on the sheet pile wall well presents " $R$ " type distribution, so the finite element software ABAQUS geotechnical problem is feasible.

(2) It assumes that the earth pressure on the sheet pile between rigid connection and hinged is different, when simulating practical engineering, we should simplify the processing according to the actual connection between sheet pile.

(3) All the conclusion of this article is based on no account of lateral force of the sheet pile wall along the wharf shoreline direction, the contact friction setting between the pile is not applicable for steel sheet pile.

\section{References}

[1] Da Chen, Xiao Wang. The summarize of the earth pressure on sheet pile wall with the influence of lateral deflection 《Channel port》, 2016.01;

[2] Li-an Han, Yu-yao Xi. Port hydraulic structures. People's traffic press, 2001;

[3] Kang Fei. Jian-wei Zhang. Gui-jun Han. ABAQUS in geotechnical engineering, China Water Power Press (in Chinese). 2009; 
[4] Yi-ping Shi, Yu-rong Zhou. ABAQUS finite element analysis example explanation. Mechanical industry press 2006; 